\title{
Study of Preservative Effect of "Propolis" on the Storage Quality of Mashed Potatoes
}

\author{
Nawal H.Bahtiti \\ Applied Science University (Private) Amman-Jordan \\ *Corresponding Author: nawal_ha@yahoo.com
}

Copyright (C 2013 Horizon Research Publishing All rights reserved.

\begin{abstract}
In this study, the possibility of natural antimicrobial compounds, Jordanian propolis as food preservatives is investigated. The experiment was conducted in the laboratories of basic science-allied medical science, at applied science university during April -July 2013 to optimize the preservative for safe storage of mashed potatoes preparing from fresh boiled potatoes. Approved chemical preservatives have been widely used to preserve foods and increase their shelf life. There are increasing demands of the partial or complete removal of chemical preservatives from foods because of adverse health effect of chemicals. Propolis sample was collected from naour region. The antimicrobial activities of propolis against several food spoilage microorganisms were examined. Escherichia coli, Bacillus cereus, Candida albicans, and Staphylococcus aurous, as food poisoning microorganisms were chosen. The post-processing development of contaminating microorganisms present in stored mashed potatoes was controlled effectively with 100,200 , and $400 \mathrm{ppm}$ of Jordanian propolis. Among these preservatives, 400ppm honey gum showed better sensory quality attributes in respect of color, flavor, texture and taste during four months of storage at room temperature, which is better than $400 \mathrm{ppm}$ of sodium benzoate preservatives. Antimicrobial effect was tested during storage at $25^{\circ} \mathrm{C}$. When the microorganisms were treated with propolis, the population of food spoilage microorganisms decreased by $2.6-3.7 \mathrm{log}$ cycles. The inhibitory effect was increased in more acidic condition. Propolis was effective at preventing microbial growth and extending shelf-life.
\end{abstract}

Keywords Mashed potatoes, sensory evaluation, microorganisms, sodium benzoate, and Jordanian propolis.

\section{Introduction}

Propolis is a mixture of various amounts of beeswax and resins collected by the honeybee from plants, particularly from flowers and leaf buds and mixed with some saliva and other secretions of the bees as well as with wax. These resins are used by worker bees to line the inside of nest cavities and all brood combs, repair combs, seal small cracks in the hive.

These uses are significant because they take advantage of the antibacterial and antifungal effects of propolis in protecting the colony against diseases. Propolis has been shown to kill the bee's most ardent bacterial foe, Bacillus larvae - the cause of American Foul Brood Mlagan and Sulimanovic, [1]; Merest and Meresta, [2] The use of propolis thus reduces the chance of infection in the developing brood and the growth of decomposing bacteria in dead animal tissue. [3].

In the natural distribution ranges of Apis mellifera, a multitude of traditional uses are known for this versatile substance. The Greeks and Romans already knew that propolis would heal skin abscesses and through the centuries its use in medicine has received varying attention. The ancient Egyptians knew about the benefits of propolis and in Africa it is still used today, as a medicine, an adhesive for tuning drums, sealing cracked water containers or canoes and dozens of other uses. There are many uses of propolis or its extracts have been found in literature as inhibiting plant and seed germination, Donadieu [4] in general and potato leaf salad seed germination in particular, Bianchi, et al [5]. Potato is a versatile, carbohydrate-rich food highly popular worldwide and prepared and served in a variety of ways, approved chemical preservatives have been widely used to preserve potatoes and increase their shelf life. There are increasing demands of the partial or complete removal of chemical preservatives from foods because of adverse health effect of chemicals. [6]. The antioxidant, antimicrobial and antifungal activities of propolis offer scope for applications in food technology. One special advantage is that, unlike some conventional preservatives, the residues of propolis seem to have a generally beneficial effect on human health. However, only very few studies have been done on the possible side-effects of increased consumption of propolis. Individually, some of the components identified in propolis can be very damaging to human health. Mizuno [7] registered a patent which includes propolis as a preservative in food packing material. Extension of frozen storage life of 
fish by 2-3 times is cited including Donadieu [4], but without reference to original studies. Propolis is permitted as a preservative for frozen fish. by various authors, In Japan, the use of Addition of only $30 \mathrm{ppm}$ (parts per million) of propolis to the rations of laying hens increased egg production, food conversion and hen weight by $\mathrm{S}$ to $6 \%$ (Bonomi, et al.,[8] and. Ghisalberti [9] reports additional weight gains for broiler chicken of up to $20 \%$ when $500 \mathrm{ppm}$ of propolis was added to their diets. In this study, the possibility of natural antimicrobial compounds, Jordanian propolis as food preservatives is investigated. [10-12]

\section{Materials and Methods}

The experiment was conducted in the laboratories of basic science-allied medical science, at applied science university during April -July 2013 .Fresh Jordanian potatoes were boiled and mashed .Fresh Jordanian propolis were obtained from naour region. Different levels of propolis were used as a preservative as per following treatments-

$\mathrm{T} 1=0.10 \mathrm{~g}$ mashed potatoes with $0 \mathrm{ppm}$ propolis

$\mathrm{T} 2=0.10 \mathrm{~g}$ mashed potatoes with $100 \mathrm{ppm}$ propolis

$\mathrm{T} 3=0.10 \mathrm{~g}$ mashed potatoes with $200 \mathrm{ppm}$ propolis

$\mathrm{T} 4=0.10 \mathrm{~g}$ mashed potatoes with $400 \mathrm{ppm}$ propolis

$\mathrm{T} 5=0.10 \mathrm{~g}$ mashed potatoes with $400 \mathrm{ppm}$ sodium benzoate.

\section{Estimation of moisture and carbohydrate}

The percent of moisture in the sample was estimated by the standard procedure as recommended by (Tarioul , 2007)

\section{Physico-chemical characteristics of samples}

Physico-chemical analyses ( $\mathrm{pH}$, quality characteristics) of samples were examined by using ISI methods ( Barnett and Hunter 1972).

\section{Sensory evaluation of samples}

Samples were examined by the method described by Govindarajan et al., (1972) for their quality

Parameters like color, aroma, taste, texture and overall acceptability. For statistical analysis of sensory data, a 1-9 point hedonic scale was used to assess the degree of acceptability of samples. The highest score is 9 'like extremely 'and 'dislike extremely' is the lowest score of 1 .
The data were analyzed for ANOVA in completely randomized design (CRD) under computerized statistical methods of M-stat and least significant difference (LSD) was used to compare the means. The results were evaluated by Analysis of variance and Duncan's New Multiple Range Test procedures of the Statistical Analysis System (SAS, 1985).

\section{Microbial test MIC of samples}

Staphylococcus aureus (S. aureus),), Bacillus cereus ,Escherichia coli (E. coli) and Candida albicans (C.albicans) were cultured in $0.08-1.0 \%$ (weight/volume) diluted in broth. Four types of polymicrobial cultures were prepared by culturing the isolates with each other in broth (control) and broth containing various concentrations of propolis. Microbial growth was assessed on solid plate media after $24 \mathrm{~h}$ incubation.

\section{Results and Discussion}

\section{Effect of chemical composition and microbial infestation of stored potatoes}

Data presented in Table 1 revealed that the moisture content of sample packed in polyethylene bags slightly decreased in T1, T2, T3, T4 and T5 for the first two months of storage and it was $11.20 \%, 11.30 \%, 11.25 \%, 11.15 \%$ and $11.27 \%$ respectively. After the next two months, it was slightly increased in all treatments. This may be due to variation in atmospheric relative humidity that ranged from 42 to $65 \%$ during first two months and $55-85 \%$ during next two months of storage period. The initial carbohydrate content in T1, T2, T3, T4 and T5 was observed 35.20, 35.15, $35.27,35.22$ and $35.29 \%$ respectively, after the next two months, it was observed $35.17,35.16,35.19,35.15$ and $35.10 \%$ respectively. There was very little changed in carbohydrate content during four months of storage at room temperature. Initially the $\mathrm{pH}$ was found 7.5, 7.5, 7.6, 7.7 and 7.7 in $\mathrm{T} 1$, $\mathrm{T} 2$, T3, T4 and T5 respectively. The $\mathrm{pH}$ of the sample was gradually decreased in all treatments during storage periods. From the Table 2, it was observed that all the treatments were free from insect and microbial infestation up to two months of storage. After four months of storage T1 (aspergillums) and T5 (bacteria) were infested by micro organism. The other treatments were free from insect and microbial infestation up to four months of storage (Table 2).

Table 1. Physical and Chemical Parameter of Propolis - Potatoes Samples During Storage.

\begin{tabular}{|c|c|c|c|c|c|c|c|c|c|}
\hline Treatments & \multicolumn{3}{|c|}{ Moisture (\%) } & \multicolumn{3}{c|}{ Carbohydrate (\%) } & \multicolumn{3}{c|}{$\mathrm{pH}$} \\
\hline & $0 \mathrm{~m}$ & $2 \mathrm{~m}$ & $4 \mathrm{~m}$ & $0 \mathrm{~m}$ & $2 \mathrm{~m}$ & $4 \mathrm{~m}$ & $0 \mathrm{~m}$ & $2 \mathrm{~m}$ & $4 \mathrm{~m}$ \\
\hline T1 & 11.30 & 11.20 & 11.37 & 35.2 & 35.17 & 35.16 & 7.5 & 7.2 & 7.0 \\
\hline T2 & 11.35 & 11.30 & 11.40 & 35.15 & 35.16 & 35.15 & 7.5 & 7.3 & 7.0 \\
\hline T3 & 11.32 & 11.25 & 11.39 & 35.27 & 35.19 & 23.18 & 7.6 & 7.3 & 6.9 \\
\hline T4 & 11.27 & 11.15 & 11.35 & 35.22 & 35.15 & 23.14 & 7.7 & 7.4 & 7.2 \\
\hline T5 & 11.35 & 11.27 & 11.39 & 35.29 & 35.10 & 23.10 & 7.7 & 7.4 & 7.2 \\
\hline
\end{tabular}

Note: $\mathrm{m}=$ Month 


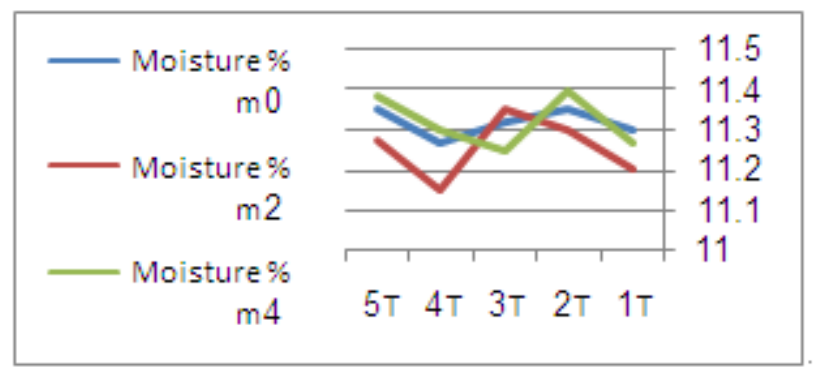

Figure 1. Moisture Percent During Four Months.

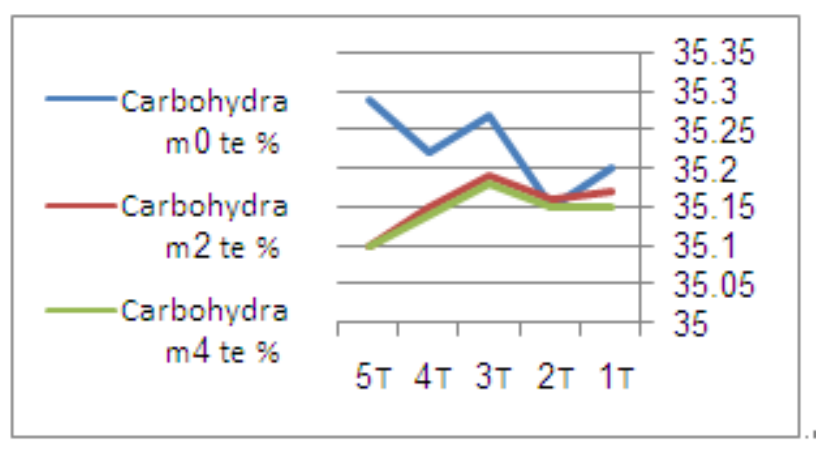

Figure 2. Carbohydrate percent during four months

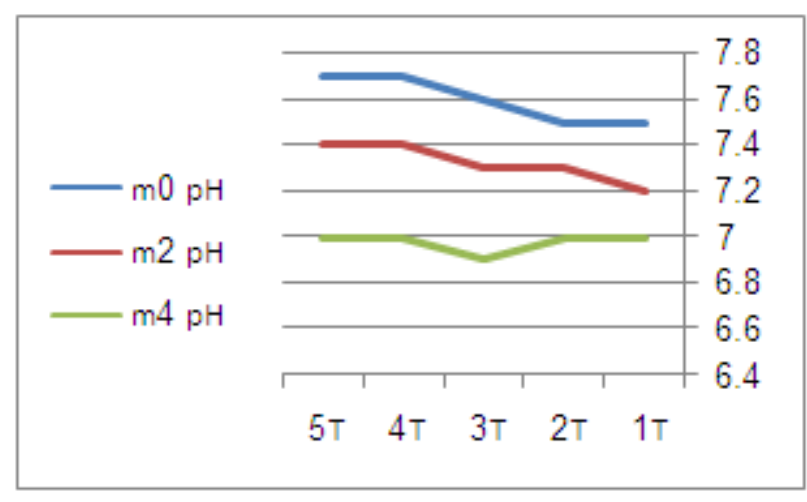

Figure 3. pH Change During Four onths

Table 2. Microbial Infestation of Stored Potatoes.

\begin{tabular}{|c|c|c|c|}
\hline \multicolumn{4}{|c|}{ Storage period (month) } \\
\hline Treatments & $0 \mathrm{~m}$ & $2 \mathrm{~m}$ & $4 \mathrm{~m}$ \\
\hline $\mathrm{T} 1$ & - & - & $+\mathrm{a}$ and $+\mathrm{b}$ \\
\hline $\mathrm{T} 2$ & - & - & - \\
\hline $\mathrm{T} 3$ & - & - & - \\
\hline $\mathrm{T} 4$ & - & - & - \\
\hline $\mathrm{T} 5$ & - & - & $+\mathrm{a}$ and $+\mathrm{b}$ \\
\hline
\end{tabular}

Note: $\mathrm{a}=$ aspergillums, $\mathrm{b}=$ bacteria

(+ Present, and - absence)

\section{Quality characteristics and sensory evaluation of potatoes samples}

Propolis samples were evaluated for quality parameters such as visual colour, texture and odor by panel
Presented in Table 3. Mixed samples with 400ppm sodium benzoate was performed yellowish colour with crispy and dissolving texture and good appetizing and rest of them developed off flavour. The effect of propolis on sensory test parameter for stored potatoes revealed that it had a positive effect (Table 3). From the visual observation of potatoes, it was found that addition of propolis improving the colour of the samples. Data present in Table 4 revealed that the $\mathrm{T}_{3}$ (8.25) had the higher score for overall acceptability considering colour, flavour, texture and taste followed by $\mathrm{T}_{4}$ (7.32) and $\mathrm{T}_{2}(7.23)$.

Table 3. Quality Characteristics of Potatoes Samples

\begin{tabular}{|c|c|c|c|}
\hline Treatments & Colour & Texture & Odor \\
\hline $\mathrm{T} 1$ & Light brown & Hard and brittle & off flavour \\
\hline $\mathrm{T} 2$ & Straw yellow & Hard and brittle & Appetizing \\
\hline $\mathrm{T} 3$ & Yellowish & $\begin{array}{c}\text { Crisp and } \\
\text { dissolving }\end{array}$ & Appetizing \\
\hline $\mathrm{T} 4$ & Deep brown & Hard and brittle & Appetizing \\
\hline $\mathrm{T} 5$ & Deep brown & $\begin{array}{c}\text { Brittle and } \\
\text { dissolving }\end{array}$ & $\begin{array}{c}\text { Slight off } \\
\text { flavour }\end{array}$ \\
\hline
\end{tabular}

Table 4. Sensory evaluation of potatoes samples after four months of storage

\begin{tabular}{|c|c|c|c|c|c|}
\hline Treatments & Colour & Flavour & Texture & Taste & $\begin{array}{c}\text { Overall } \\
\text { acceptability }\end{array}$ \\
\hline T1 & $5.63 \mathrm{c}$ & $6.77 \mathrm{c}$ & $7.22 \mathrm{a}$ & $7.22 \mathrm{~b}$ & $6.81 \mathrm{c}$ \\
\hline T2 & $6.68 \mathrm{~b}$ & $7.25 \mathrm{~b}$ & $7.20 \mathrm{a}$ & $7.12 \mathrm{c}$ & $7.02 \mathrm{~b}$ \\
\hline T3 & $7.69 \mathrm{a}$ & $8.35 \mathrm{a}$ & $7.58 \mathrm{a}$ & $8.59 \mathrm{a}$ & $8.25 \mathrm{a}$ \\
\hline T4 & $7.29 \mathrm{a}$ & $7.35 \mathrm{~b}$ & $7.33 \mathrm{a}$ & $7.26 \mathrm{~b}$ & $7.32 \mathrm{~b}$ \\
\hline T5 & $6.02 \mathrm{a}$ & $6.33 \mathrm{~b}$ & $7.20 \mathrm{a}$ & $7.22 \mathrm{~b}$ & $6.83 \mathrm{~b}$ \\
\hline
\end{tabular}

${ }^{\mathrm{a}}$ : Profile Attribute Analysis [13]

${ }^{\mathrm{b}}$ :Texture Profile Method [14]

${ }^{\mathrm{c}}$ :Revised Math Attitude Scale [15]

Table 5. -Antimicrobial activity of propolis (ug/ml).

\begin{tabular}{|c|c|}
\hline Microorganisms & $\mathrm{ug} / \mathrm{ml}$ \\
\hline Escherichia coli (E. coli) & 62.5 \\
\hline Bacillus cereus (B.cereus) & 125 \\
\hline Candida albicans & 31.5 \\
\hline Staphylococcus aurous & 62.5 \\
\hline
\end{tabular}

\section{Conclusion}

In conclusion, propolis prevents the growth of the microorganisms in single and mixed microbial cultures, it may be stated that the addition of sodium benzoate (400ppm) with equally mixed propolis sample, was not effective as propolis of acceptable quality for 4 months of storage at room temperature. No micro organism was grown in stored propolis-potatoes samples. It was fully safety to consumer. As multifunctional bioactivity ingredients, propolis can be used as ant oxidative, antibacterial agent and coating-preservative agent. It is characteristic of natural, 
nutritional and safe.

\section{Acknowledgements}

The author acknowledges Applied Science Private University, Amman, Jordan, for the fully financial support granted of this research article. Sincere thanks to all my colleagues at basic science-chemistry department, for creating inspiring conditions for work.

\section{REFERENCES}

[1] V. Mlagan, and D. Sulimanovic,. Action of propolis solutions on Bacillus larvae. Apiacta, 17: 16-20. 1982

[2] T. Meresta and Merest .Sensitivity of Bacillus larvae to an extract of propolis in vitro. Medycyna Weterynajja, 44(3): 169-170. 1988.

[3] "http://www.naturalnews.com/022160 food additives natur al foods.html">Propolis could be ${ }^{-}{ }^{-}$as a natural non-toxic food preservative $</ a>$

[4] Y., Donadieu, La Propolis. Editions Maloine, Paris .1979

[5] Bianchi, et al. Ultrastructural studies of the effects of germination and survival of weed seeds in soil. Weed Sci., 38, pp. 429-435. 1991
[6] M. Miarudoin et al. Study on the effect of preservatives on the storage quality of spiced papads . innov.dev.strategy. 3(1): 2009

[7] Y. Mizuno . Biochemical and Biophysical Research Communications $163(3): 1450-1455.1989$

[8] Bonomi,.et al. Propolis in feeds for laying hens. Avicoltura, 54: 43-54., 1976

[9] E.Ghisalberti,. Propolis: A review. Bee World, 60: 59-84: 1979

[10] S.,K.Shalmany and M. Shivazad The Effect of Diet Propolis Supplementation on Ross Broiler Chicks Performance International Journal of Poultry Science 5 (1): 84-88, 2006

[11] T.Islami Standarization of Bread Preparation from Soy Flour. Int. J. Sustain. Crop Prod. 2(6):15-20 . 2007

[12] R., Govindarajan, et al.Antioxidant .Approach to Disease Menagement and the Role of 'Rasayana' Herbs of Ayurveda. J. Ethnopharmacol. 99:165-178. 2005.

[13] L. Averette et al. Descriptive flavor analysis of bacon Journal: Food Quality and Preference - vol. 21, no. 1, pp. 44-55, 2010

[14] A. Drewnowski .Individual differences in sensory preferences for fat in model sweet dairy products Acta Psychologica 84 ,103-110, 1993.

[15] Stone et al. Factors influencing mathematical competencies. Community Junior College Research Quarterly Volume 5, Issue 1,1980 